expressed hy all who take an interest in the hospital, and the satisfaction of knowing that in a few months a new, properly equipped building and trained assistance will be at her disposal-surely these are things worth some sacrifice! There are too higher and holier compensations which strengthen her hands in well-doing.

Twenty-three hranches of the order have been estahlished in less than three years. In five of these the work has been carried on in cottage hospitals, hut just as fine results have been achieved hy the nurse in the district. Many an infant owes his eyesight to her attention and to her carefully instructing the mother how to carry on the same treatment in her ahsence; many a mother has been saved from septicæmia by the precautions which only a trained nurse knows how to take; and cleanliness and order have been permanently estahlished in not a few homes through the force of her example.

It is hoped that these sketches of the training and of the character of the work in the Victorian Order will appeal to many, and that the new year will bring into the ranks of the order women who are ready, hy training, and willing, through love and the desire to serve, to ohey the command,-

"Whatsoever He saith unto you, do it."

Chardote Maction, Chief Lady Superintendent.

\title{
LETTERS
}

\section{FROM OUR ENGLISH CORRESPONDENT}

\section{QUERN VICTORIA AND THE PROFESSION OF NURSINO}

Dear EDitor: Just now, when we are all grieving over the death of our great and good Queen, and all eyes are turned upon her personality, a few words concerning her in her relation to nursing will be timely. The Queen's reign has seen the dawn and the extraordinary development of scientific nursing, for until the time of the Crimean War nursing, as we understand it, was unknown. Queen Victoria followed with the keenest interest the work of Miss Florence Nightingale and her colleagues in the Crimea, and later gave practical evidence of this hy laying the foundation-stone of St. Thomas's Hospital when the present magnificent structure was erected, and the Nightingale School was founded in connection with it. Notahle events in the Queen's reign in relation to nursing have been the estahlishment of the Army, Navy, and Indian Army Nursing Services. As at present constituted these organizations are merely the nucleus of what will eventually become efficient State departments for the careful nursing of our soldiers irrespective of rank. During her reign Queen Victoria paid constant visits to the Royal Military Hospital at Netley, and as a special mark of her recognition she instituted in 1883 the order of the Royal Red Cross "For zeal and devotion in providing for and nursing sick soldiers, sailors, and others with the army in the field, on board ship, or in hospitals." Foreign as well as British suhjects are eligihle.

In 1887 the Queen Victoria Jubilee Institute was founded hy her for supplying district nurses to the poor in their own homes. The Queen devoted to this purpose the sum of seventy thousand pounds, the Juhilee offering of the women of England, and it is with this branch of nursing that her name will be forever associated. 
Not only in England, but in Scotland, Ireland, and Wales Queen's nurses are now at work, the head-quarters of the institute being at St. Katherine's Hospital, London. The president is the master of St. Katherine's, a clergyman of the English church, a curious appointment, the origin of which, no doubt, comes down to us from mediæval times, when brethren and sisters lived a conventual life in obedience to the direction of their appointed master, but one which is out of, touch with the present age, when the active control of a man unversed in nursing requirements in an association of trained nurses appears an anomaly.

In 1891 the Queen once more showed her practical interest in nursing by granting the prefix "Royal" to the British Nurses' Association, founded upon the initiation of Mrs. Bedford Fenwick and some public-spirited matrons, to obtain legal status for trained nurses, and in order that they might enjoy the benefits of professional cooperation, and again in 1893, when the matrons who had founded it had an effective share in its management and the association was at the height of its power and usefulness, it was granted a royal charter by the Queen in Council.

UnTON JACK.

(To be continued.)

\section{A MODERN ASSOCIATION IN GERMANY}

[The following account of the work of an association which demonstrates vividly the world-wide pressure of the "woman's movement" towards fuller selfdevelopment and personal freedom has been kindly written for the JoukraL by Lady Brandis, wife of Sir Dietrich Brandis, a scientific man of much prominence.—ED.]

\section{Bonn, Katger Strasse.}

The Ammrican Jourinat of Nugsive.

Dear Editor: As you think that some information about the "Diakonie Verein" may be interesting to your readers, I shall try and give you a little sketch of its guiding principles.

The "Diakonie Verein," which has now been in working order for flve years, owes its existence to Professor Zimmer, its present director, formerly superior of a theological seminary in the province of Hessen, Nassau.

Years ago Professor Zimmer recognized the necessity of creating new flelds of labor for young ladies of good education who were desirous of devoting their strength and energy to philanthropic work, but who did not feel disposed to enter a deaconesses' institution.

In framing the rules for this new undertaking Professor Zimmer was guided by the idea that the sisters joining the "Diakonie Verein" should, as much as possible, retain their individual freedom and independence. The outcome of this principle is that those sisters who have been finally accepted into the inner sisterhood are permitted to share largely in the management of the affairs of the "Verein."

A young lady wishing to enter the "Verein" has first to choose her branch, of which there are three, one for nursing, the educational one, and that for household economy. If, for instance, she wishes to go in for the one of nursing, 
she has to apply to one of the lady superiors of a district and has to submit a curriculum vita, a health report, and her college certificates. If these testimonials are found to be satisfactory, she is admitted to one of the seminaries of the "Verein;" the seminary is not a college, but means practical training in a large hospital under close supervision and with theoretical instruction given by the leading physician and his staff.

In the majority of cases the lady superior of a district is at the same time the superior of the whole nursing establishment of her hospital, but she may also have sisters of the other hranches in her district under her superintendence. It will be seen that her post is a most important one with varied duties, and can only be filled by a sister with a wide experience. The young sister having finished her training in the seminary, the shortest duration of which lasts a year, has to pass an examination, and if she has been successful she is now fit to accept a post and to receive salary. For the next year she is a prohational sister and is mostly placed by the authorities which preside over the Verein under the eyes of an experienced sister. The probation year being over, other places can be offered to her, and it is left to her own decision to accept as she likes. She will either have charge of a ward in a hospital and eventually teach novices, or she may accept the work of a parish sister. From elther position she can rise to the higher posts the "Verein" has to offer. She will probably belong for a few years to the outer circle, called "Vereinsschwestern," and she may then be admitted by election into the inner circle, called "Verbands. schwestern."

Her holidays are limited to three or four weeks in the year, and it is obligatory for her to subscribe to a pension fund. It is, however, possible for a sister to retire for a longer period from the field of labor, if family duties or ill-health oblige her to do so. Should she wish to leave the Verein altogether, she has to give three-months' notice.

The authorities above mentioned consist of the "Vereinsdirektor," who is supported by a committee and appointed heads of various departments.

How much an undertaking of this kind was needed in Germany is best shown by the number of sisters who now belong to the "Verein," who are grateful for the opportunities thereby offered to them, and by the constant influx of new applications. There is a strong esprit de corps already developed among the sisters, especially among those who belong to the inner circle.

It is necessary, finally, to add that the "Evangelische Diakonieverein," which is absolutely self-supporting, is limited to sisters belonging to the Protestant religion.

Katherine Brandis. 